\title{
Üniversite Öğrencilerinin Rekreasyonel Etkinliklere Katılımlarına Engel Olan Faktörlerin İncelenmesi (Üsküdar Üniversitesi Örneği)*
}

\section{Investigation of the Factors that Hinder Participation of Recreational Activities of University Students (The Case of Uskudar University)}

\author{
ORIJINAL ARAŞTIRMA/ \\ ORIGINAL RESEARCH \\ Orhan Şükrü BOSNA ${ }^{\mathbf{1}}$, \\ Betül BAYAZIT ${ }^{2}$, \\ Ozan YILMAZ ${ }^{3}$
}

${ }^{1}$ Kocaeli Üniversitesi, Spor Bilimleri Fakültesi, https://orcid.org/0000-0002-4946-4290 ${ }^{2}$ Kocaeli Üniversitesi, Spor Bilimleri Fakültesi, https://orcid.org/0000-0003-3547-2035 ${ }^{3}$ Kocaeli Üniversitesi, Sağlik Bilimleri Enstitüsü, Beden Eğitimi ve Spor Anabilim Dalı Mezunu, https://orcid.org/0000-0001-5889-7365

\section{$\ddot{\mathbf{O z}}$}

$\mathrm{Bu}$ araştırmada, Üsküdar Üniversitesi'nde okuyan öğrencilerin rekreasyonel etkinliklere katılımına engel olan faktörlerin incelenmesi amaçlanmıștır. Araștırmaya, Üsküdar Üniversitesi'nde okuyan 96's1 erkek, 99'u kadın olmak üzere toplam 195 öğrenci gönüllü olarak katılmıştır. Veri toplama aracı olarak Alexandris ve Carroll (1997) tarafindan geliştirilen, Türkçe uyarlaması, geçerlik ve güvenirlik çalışması Gürbüz ve Karaküçük (2007) tarafindan yapılan "Boş Zaman Engelleri" ölçeği kullanılmıştır. Ölçek, toplam 6 alt boyut ve 27 maddeden oluşmaktadır. Elde edilen veriler, SPSS 21.0 paket programı ile analiz edilmiştir. Araştırmada kullanılan boş zaman engelleri ölçeğinden elde edilen verilerin frekans ve yüzde değerleri alındıktan sonra parametrik testlerden Bağımsız Örneklem T-Testi (independent sample t-test) ve ANOVA testi uygulanmıştır. Anlam düzeyi 0.05 olarak alınmıştır.

Elde edilen bulgulara göre, Üsküdar Üniversitesi öğrencilerinin rekreatif etkinliklere katılımını etkileyen faktörlerde büyük bir farklılığın olmadığı görülmektedir. "Cinsiyet" ve "Bölüm” değişkenlerine göre karşılaştırıldığında alt boyutlarda istatistiksel olarak anlamlı bir farklılık bulunmamıştır ( $p>0.05)$. "Sınıf" değişkenine göre karşılaştırıldığında ise alt boyutlarda "zaman ve ilgi eksikliği" ile "birey psikolojisi" alt boyutlarında istatistiksel olarak anlamlı bir farklılık bulunmuştur $(\mathrm{p}<0.05)$.

Anahtar Kelimeler: Rekreasyon, boş zaman engelleri, üniversite öğrencileri

\section{Yayın Bilgisi}

Gönderi Tarihi: 08.12.2017

Kabul Tarihi: 20.12.2018

Online Yayın Tarihi: 31.12.2018

\begin{abstract}
In this research, it was aimed to investigation of the factors that hinder participation of recreational activities of university students. A total of 195 students, 96 males and 99 females attending Üsküdar University, voluntarily participated in the research. As a data collection tool, the validity and reliability study of Turkish adaptation developed by Alexandris and Carroll (1997) is used on Gürbüz and Karaküçük (2007) "Leisure Time Barriers" scale. The scale consists of 6 sub-dimensions and 27 items. The obtained data were analyzed with SPSS 21.0 package program. Independent sample ttest and ANOVA test were applied to the parametric tests after the frequency and percentage values of the data obtained from the time-of-use barriers used in the study were taken.Meaning level is taken as 0.05 .

According to the findings, it is seen that there is not a big difference in the factors that affect the participation of Üskudar University students in recreational activities. There was no statistically significant difference in the sub-dimensions when compared to the variables of "Gender" and "Department" ( $p>0.05$ ). Compared to the "class" variable, there was a statistically significant difference in the subscales of "time and interest incompleteness" and "individual psychology" sub - dimensions ( $\mathrm{p}<0.05)$.
\end{abstract}

Keywords: Recreation, leisure constraints, university students

* Bu çalışma 23- 26 Kasım 2017 tarihleri arasında Manisa'da düzenlenen Dünya Spor Bilimleri Araştırmaları Kongresi’nde sözel bildiri olarak sunulmuştur.

† Sorumlu yazar: Orhan Şükrü BOSNA, s.bosna@hotmail.com 


\section{GİRIŞ̧}

Günümüz insanı şimdiye kadar hiçbir insanın sahip olamadığg kadar serbest zamanlarını değerlendirme olanaklarına sahip olarak görülmektedir. İnsanın dinlenme, rahatlama, bilgi ve görgüsünü arttırma, psikolojik ve fizyolojik olarak insan hayatının özel bir alanıdır (Yetim, 2005). Serbest zaman yaşamın pratik ihtiyaçlarını yerine getirdikten sonra geriye kalan zaman dilimi olarak da tanımlanmaktadır (Torkildsen, 2005). Kemp ve Pearson'a (1997) göre ise serbest zaman; çalışma, uyku, yemek yeme ve diğer zorunlu işler için ayrılan vakit sonrasında arta kalan zaman dilimidir. Günlük yaşantımız içinde, çalışma ve diğer etkinliklerimizin sıkıcı ve kendini tekrarlayan çabalara dönüşmesi, serbest zaman değerlendirme etkinliklerini yaşamımızın önemli bir parçası haline getirmiştir (Özşaker, 2012). Serbest zaman etkinlikleri, bireyin yaşamındaki birçok sıkıntıdan kurtulmasını ve bireyin kendisini geliştirmesini sağlayarak, bireylerin kendilerine, ilişkilerine ve sosyokültürel uyumlarını olumlu yönde etkilemektedir. (Axelsen, 2009; Iwasaki, 2007; Şener, Terzioğlu ve Karabulut, 2007). Bireyler serbest zamanlarında; dinlenmek, iş stresinden uzaklaşmak, eğlenmek, sosyalleşmek gibi amaçlarla açık veya kapalı alanlarda, aktif veya pasif şekilde, gönüllü olarak çeşitli etkinliklere katılmaktadırlar. İnsanlar sahip olduğu bu zaman dilimini bazen bireysel olarak bazen de grup olarak değerlendirebilirler. Son dönemlerde yapılan pek çok çalışmanın sonuçlarına göre ise bireylerin serbest zamanlarını daha çok pasif etkinliklere katılarak ya da hiçbir etkinliğe katılmayarak değerlendirdikleri tespit edilmiştir (Temir ve Gürbüz, 2012).

Kampüse sahip her kurum için geçerli olan kampüs rekreasyon mekan ve etkinlikleri kampus özelliklerine göre farklılıklar gösterebilir. Fakat kampüs rekreasyonunun en dikkat çekici yönü tüm üniversite mensuplarına, öğrenci ve öğrenci ailelerine, personel ve personel ailelerine çok yönlü program ve hizmetler sunmasıdır. Bu programlar katılımcı özelliklerine göre çeşitli ve amaca yönelik hazırlanırlar. Kampüs rekreasyonu ciddi bir tesisleşmeyi gerektirdiği gibi bu tesislerin verimli kullanımını sağlayacak personel istihdamını da ön görür. Bu tesislerin en mantıklı şekilde gün boyu verimli kullanılması hem hizmetlerin sunulması hem de üniversite mensuplarına fayda sağlanması açısından önem taşır (Kaba, 2009). Üniversite gençlerinin boş zamanlarını değerlendirmeleri ve rekreasyon etkinliklerine katılımları, üniversite eğitimleri süresinde okulların kendilerine sunduğu olanaklar kapsamında yarı örgütlü bir şekilde gerçekleşmekte; bu bağlamda üniversiteler öğrencilerinin resmî eğitimleri dışında kalan 
zamanlarını iyi bir şekilde değerlendirmeleri için de yönlendirici rol üstlenebilmektedirler (Balc1, 2003). Literatürde yer alan ve bireylerin rekreasyonel aktivitelere katılmalarına engel teşkil eden unsurların belirlenmesine yönelik yapılan model geliştirme çalışmalarının sonuçlarına göre etkinliklere katılımı engelleyen veya kısıtlayan faktörlerin; bireysel, bireylerarası ve yapısal olarak üç temel grupta ele alınabileceği ortaya konmuştur. Rekreasyonel aktivitelere katılımın pozitif etkileri düşünüldügünde bu tür aktivitelere katılımı engelleyen faktörlerin belirlenmesi hem bireysel hem de toplumsal anlamda önem arz etmektedir (Temir ve Gürbüz, 2012). Üniversite gençlerinin boş zamanlarını değerlendirmeleri ve rekreasyon etkinliklerine katılımları, üniversite eğitimleri süresinde okulların kendilerine sunduğu olanaklar kapsamında yarı örgütlü bir şekilde gerçekleşmekte; bu bağlamda üniversiteler öğrencilerinin resmî eğitimleri dışında kalan zamanlarını iyi bir şekilde değerlendirmeleri için de yönlendirici rol üstlenebilmektedirler (Balcı, 2003). Aynı zamanda öğrenciler okullardaki boş zaman faaliyetlerine katılmakla, kendi boş zaman saatlerini geliştirebilmelerini sağlayacak ilgi ve becerileri kazanmaktadırlar (Hendry ve Marr, 1985). Üniversite öğrencilerinin boş zaman aktivitelerinin organizasyonlu bir biçimde yönlendirilmesi, özellikle sportif aktivitelere katılımlarının sağlanması öğrencilerin fiziksel ve ruhsal sağlıkları açısından olumlu etki gösterip uzun vadede öğrencilerin başarı oranları, hatta üniversitelerin kalite ölçütlerine katkıda bulunacaktır (Guo ve Liu, 2016). Bu bağlamda yapılan araştırmada, Üsküdar Üniversitesi'nde okuyan öğrencilerin rekreasyonel etkinliklere katılımına engel olan faktörlerin incelenmesi amaçlanmıştır.

\section{GEREÇ VE YÖNTEM}

\section{Araştırma Grubu}

Araştırmaya, Üsküdar Üniversitesi'nde okuyan 96'sı erkek, 99'u kadın olmak üzere toplam 195 öğrenci (Psikoloji programından 73, Felsefe programından 77, Sosyoloji programından 16, Siyaset Bilimi ve Uluslararası İlişkiler programından 15, Diğer programlardan 14) gönüllü olarak katılmıştır.

\section{Veri Toplama Araçları}

Çalışmada, veri toplama aracı olarak; Alexandris ve Carroll (1997) tarafından geliştirilen, Türkçe uyarlaması geçerlik ve güvenirlik çalışması Gürbüz ve Karaküçük (2007) tarafından 
yapılan "Boş Zaman Engelleri Ölçeğì" kullanılmıştır. Ölçek, toplam 6 alt boyut ve 27 maddeden oluşmaktadır. Ölçek, bireyleri Boş Zaman Engellerini belirlemeye iten, (1) "zaman ve ilgi eksikliği”, (2) "birey psikolojisi”, (3) "bilgi eksikliği”, (4) "ulaşım sorunu”, (5) "tesis yetersizliği” ve (6) "arkadaş eksikliği” olmak üzere 6 alt boyutta ölçmeye yönelik 27 maddeden oluşmaktadır. Bireylerin Boş Zaman Engelleri, "Kesinlikle Önemsiz (1)" ve "Önemsiz (2)", “Önemli (3)”, ve “Çok Önemli (4)” şeklinde 4'lü likert tipi ölçek üzerinde değerlendirilmektedir. Zaman ve ilgi eksikliği” 21, 22, 23, 24, 25, 26 ve 27. maddelerden, "birey psikolojisi" 1, 2, 3, 4, 5 ve 6. maddelerden, "bilgi eksikliği" 7, 8 ve 9. maddelerden, "ulaşım sorunu" 14, 15, 16 ve 17. maddelerden, "tesis yetersizliği”" 10,11, 12 ve 13. maddelerden ve "arkadaş eksikliği”" ise 18, 19 ve 20. maddelerden oluşmuştur.

\section{Verilerin Toplanması}

Anket uygulanmadan önce yetkili kişilerle görüşülüp gerekli izinler alındıktan sonra, araştırmaya gönüllü olarak katılan öğrencilere araştırmanın içeriği ve amacıyla ilgili bilgi verilmiştir.

\section{Verilerin Analizi}

Elde edilen veriler, SPSS 21.0 paket programı ile analiz edilmiştir. Araştırmada kullanılan boş zaman engelleri ölçeğinden elde edilen verilerin frekans ve yüzde değerleri alındıktan sonra parametrik testlerden olan bağımsız örneklem $t$ testi (independent sample $t$-test) ve ANOVA testi uygulanmıştır. Anlam düzeyi 0.05 olarak alınmıştır. 


\section{BULGULAR}

Tablo 1. Katılımcıların bazı değişkenlere göre dağılımı

\begin{tabular}{|c|c|c|c|}
\hline Değişkenler & & $\mathbf{N}$ & $\%$ \\
\hline \multirow{2}{*}{ Cinsiyet } & Erkek & 96 & 49.2 \\
\hline & Kadın & 99 & 50.8 \\
\hline \multirow{5}{*}{ Sinıf } & 1.sinif & 77 & 39.5 \\
\hline & 2.sinif & 39 & 20.0 \\
\hline & 3.sinif & 29 & 14.9 \\
\hline & 4.sinif & 42 & 21.5 \\
\hline & 5.sinıf ve üzeri & 8 & 4.1 \\
\hline \multirow{5}{*}{ Bölüm } & Psikoloji & 73 & 37.4 \\
\hline & Felsefe & 77 & 39.5 \\
\hline & Sosyoloji & 16 & 8.2 \\
\hline & Siyaset Bilim ve Uluslararası İlişkiler & 15 & 7.7 \\
\hline & Diğer & 14 & 7.2 \\
\hline \multirow{8}{*}{ Aile gelir durumu } & $1500-2000 \mathrm{TL}$ & 3 & 1.5 \\
\hline & $2001-2500 \mathrm{TL}$ & 14 & 7.2 \\
\hline & $2501-3000 \mathrm{TL}$ & 15 & 7.7 \\
\hline & $3001-3500 \mathrm{TL}$ & 16 & 8.2 \\
\hline & $3501-4000 \mathrm{TL}$ & 14 & 7.2 \\
\hline & $4001-4500 \mathrm{TL}$ & 14 & 7.2 \\
\hline & $4501-5000 \mathrm{TL}$ & 44 & 22.6 \\
\hline & 5000 TL ve üzeri & 75 & 38.5 \\
\hline \multirow{4}{*}{ İkamet yeri } & Ailemle & 47 & 24.1 \\
\hline & Arkadaşlarımla & 75 & 38.5 \\
\hline & Yalnız & 18 & 9.2 \\
\hline & Yurtta & 55 & 28.2 \\
\hline \multirow{3}{*}{$\begin{array}{l}\text { Yaşamının çoğunluğunu geçirdiği } \\
\text { yer }\end{array}$} & Köy/Kasaba & 7 & 3.6 \\
\hline & Şehir & 69 & 35.4 \\
\hline & Büyükşehir & 119 & 61.0 \\
\hline \multirow{5}{*}{ Haftalık boş zaman süresi } & $1-5$ saat & 23 & 11.8 \\
\hline & 6-10 saat & 67 & 34.4 \\
\hline & $11-15$ saat & 61 & 31.3 \\
\hline & 16 saat ve Üzeri & 44 & 22.6 \\
\hline & TOPLAM & 195 & 100.0 \\
\hline
\end{tabular}

Tablo 1'de, araştırmaya katılan katılımcıların cinsiyete göre 96's1 (\%49,2) erkek, 99'u $(\% 50,8)$ kadın; okuduğu sınıfa göre 1.sınıf 77 (\%39,5) öğrenci, 2.sınıf $39(\% 20,0)$ öğrenci, 3.sınıf $29(\% 14,9)$ öğrenci, 4.sınıf $42(\% 21,5)$ öğrenci, 5.sınıf ve üzeri $8(\% 4,1)$ öğrenci; eğitim aldığı bölüme göre, Psikoloji 73 (\%37,4) öğrenci, Felsefe $77(\% 39,5)$ öğrenci, Sosyoloji 16 
$(\% 8,2)$ öğrenci, Siyaset Bilim ve Uluslararası İlişkiler $15(\% 7,7)$ öğrenci, diğer değişkenine 14 $(\% 7,2)$ öğrenci bulunmaktadır. Aile gelir durumuna göre, 1500-2000 TL 3 (\%1,5) öğrenci, 20012500 TL 14 (\%7,2) öğrenci, 2501-3000 TL 15 (\%7,7) öğrenci, 3001-3500 TL 16 (\%8,2) öğrenci, 3501-4000 TL 14 (\%7,2) öğrenci, 4001-4500 TL 14 (\%7,2) öğrenci, 4501-5000 TL 44 (\%22,6) öğrenci, 5000 TL ve üzeri 75 (\%38,5) öğrenci olarak belirlenmiştir. Katılımcıların 75’i $(\% 38,5)$ arkadaşlarıyla ikamet ettiğini; 119'u (\%61,0) büyükşehirde yaşamının çoğunu geçirdiğini; 67'si $(\% 34,4)$ haftalık boş zaman sürelerinin 6-10 saat olduğunu belirtmişlerdir.

Tablo 2. Katılımcıların boş zamanlarını değerlendirmesine yönelik ifadelere göre dağılımı

\begin{tabular}{|c|c|c|c|}
\hline Değişkenler & & $\mathbf{N}$ & $\%$ \\
\hline \multirow{6}{*}{ Boş Zamanlarını Genellikle } & Ev içi aktivitelere katılarak & 17 & 8.7 \\
\hline & Fiziksel aktivitelere katılarak & 24 & 12.3 \\
\hline & Sosyal etkinliklere katılarak & 109 & 55.9 \\
\hline & Kültürel-Sanatsal etkinliklere katılarak & 29 & 14.9 \\
\hline & Açık alan etkinliklere katılarak & 9 & 4.6 \\
\hline & Diğer & 7 & 3.6 \\
\hline \multirow{5}{*}{$\begin{array}{l}\text { Üniversitesinin Sahip Olduğu } \\
\text { Rekreasyon Alanları }\end{array}$} & Kesinlikle Yetersiz & 29 & 14.9 \\
\hline & Yetersiz & 45 & 23.1 \\
\hline & Kismen & 87 & 44.6 \\
\hline & Yeterli & 34 & 17.4 \\
\hline & Kesinlikle Yeterli & - & - \\
\hline \multirow{4}{*}{$\begin{array}{l}\text { Üniversitesinin Sahip Olduğu } \\
\text { Rekreasyon Alanlarını Ne Sıklıkla } \\
\text { Kullandığı (Haftalık) }\end{array}$} & $1-5$ saat & 109 & 55.9 \\
\hline & $6-10$ saat & 60 & 30.8 \\
\hline & $11-15$ saat & 19 & 9.7 \\
\hline & 16 saat ve üzeri & 7 & 3.6 \\
\hline \multirow{5}{*}{$\begin{array}{l}\text { Yaşadığı İlin Sahip Olduğu } \\
\text { Rekreasyon Alanları }\end{array}$} & Kesinlikle Yetersiz & 22 & 11.3 \\
\hline & Yetersiz & 40 & 20.5 \\
\hline & Kismen & 70 & 35.9 \\
\hline & Yeterli & 52 & 26.7 \\
\hline & Kesinlikle Yeterli & 11 & 5.6 \\
\hline \multirow{4}{*}{$\begin{array}{l}\text { Yaşadığı İlin Sahip Olduğu Rekreasyon } \\
\text { Alanlarını Ne Sıklıkla } \\
\text { Kullandığı (Haftalık) }\end{array}$} & $1-5$ saat & 79 & 40.5 \\
\hline & $6-10$ saat & 71 & 36.4 \\
\hline & $11-15$ saat & 33 & 16.9 \\
\hline & 16 saat ve üzeri & 12 & 6.2 \\
\hline \multirow{4}{*}{$\begin{array}{l}\text { Sahip Olduğu Boş Zamanı Daha Çok } \\
\text { Nerede Değerlendirdikleri }\end{array}$} & Kampus İçi & 29 & 14.9 \\
\hline & Kampus D1ş1 & 151 & 77.4 \\
\hline & Diğger & 15 & 7.7 \\
\hline & TOPLAM & 195 & 100.0 \\
\hline
\end{tabular}


Tablo 2'de, katılımcıların 109'u (\%55,9) sosyal etkinliklere, 29’u (\%14,9) kültürelsanatsal etkinliklere, 24’ü (\%12,3) fiziksel aktivitelere, 17'si (\%8,7) ev içi aktivitelere, 9'u $(\% 4,6)$ açık alan etkinliklerine, 7'si $(\% 3,6)$ diğer etkinlik türlerine katılarak boş zamanlarını değerlendirdiklerini, \% 82.6'sı üniversitenin sahip olduğu rekreasyon alanlarının yeterli olmadığını, 109’u (\%55.9) üniversitenin sahip olduğu rekreasyon alanlarını haftada 1-5 saat arasında kullandıklarını, \% 67.7'si yaşadığı ilin sahip olduğu rekreasyon alanlarının yeterli olmadığını, 79’u (\%40.5) yaşadığı ilin sahip olduğu rekreasyon alanlarını haftada 1-5 saat arasında kullandıklarını ve 151'i $(\% 77,4)$ boş zamanlarını kampüs dışında değerlendirdiklerini belirtmişlerdir.

Tablo 3. Cinsiyete göre karşılaştırma T-testi sonuçları

\begin{tabular}{|c|c|c|c|c|c|c|}
\hline Değişkenler & Cinsiyet & $\mathbf{N}$ & Ort & SS & $\mathbf{t}$ & $\mathbf{p}$ \\
\hline \multirow{2}{*}{ Zaman ve İlgi Eksikliği } & Erkek & 96 & 19.68 & 4.80 & \multirow{2}{*}{1.089} & \multirow{2}{*}{0.277} \\
\hline & Kadın & 99 & 19.02 & 3.68 & & \\
\hline \multirow{2}{*}{ Birey Psikolojisi } & Erkek & 96 & 16.36 & 4.46 & \multirow{2}{*}{.104} & \multirow{2}{*}{0.917} \\
\hline & Kadın & 99 & 16.30 & 3.78 & & \\
\hline \multirow{2}{*}{ Bilgi Eksikliği } & Erkek & 96 & 8.01 & 2.20 & \multirow{2}{*}{-.899} & \multirow{2}{*}{0.370} \\
\hline & Kadın & 99 & 8.31 & 2.48 & & \\
\hline \multirow{2}{*}{ Ulaşım Sorunu } & Erkek & 96 & 10.72 & 2.32 & \multirow{2}{*}{.533} & \multirow{2}{*}{0.595} \\
\hline & Kadın & 99 & 10.53 & 2.73 & & \\
\hline \multirow{2}{*}{ Tesis Yetersizliği } & Erkek & 96 & 11.64 & 2.31 & \multirow{2}{*}{-1.102} & \multirow{2}{*}{0.272} \\
\hline & Kadın & 99 & 12.01 & 2.29 & & \\
\hline \multirow{2}{*}{ Arkadaş Eksikliği } & Erkek & 96 & 8.39 & 2.11 & \multirow{2}{*}{1.182} & \multirow{2}{*}{0.239} \\
\hline & Kadın & 99 & 8.03 & 2.19 & & \\
\hline
\end{tabular}

Tablo 3'te, cinsiyete göre karşılaştırma yapıldığında alt boyutlarda istatistiksel olarak anlamlı bir farklılık bulunmamıştır $(\mathrm{p}>0.05)$. 
Tablo 4. Sınıf değişkenine göre karşılaştırma ANOVA- TUKEY sonuçları

\begin{tabular}{|c|c|c|c|c|c|c|}
\hline Alt Boyutlar & Sinıf & $\mathbf{N}$ & ORT & SS & Fark & $\mathbf{p}$ \\
\hline \multirow{6}{*}{ Zaman ve İlgi Eksikliği } & 1.Sinif & 77 & 18.61 & 3.62 & \multirow{6}{*}{$5-1,2,3,4$} & \multirow{6}{*}{$0.001 *$} \\
\hline & 2.Sinıf & 39 & 19.10 & 4.51 & & \\
\hline & 3.Sinif & 29 & 18.79 & 4.56 & & \\
\hline & 4.Sinif & 42 & 20.23 & 4.33 & & \\
\hline & 5.Sinıf ve üstü & 8 & 25.00 & 3.46 & & \\
\hline & TOPLAM & 195 & 19.34 & 4.27 & & \\
\hline \multirow{6}{*}{ Birey Psikolojisi } & 1.Sinıf & 77 & 16.16 & 3.71 & \multirow{6}{*}{$3-5$} & \multirow{6}{*}{$0.023^{*}$} \\
\hline & 2.Sinif & 39 & 16.05 & 3.27 & & \\
\hline & 3.Sinıf & 29 & 15.10 & 4.69 & & \\
\hline & 4.Sinif & 42 & 17.00 & 4.83 & & \\
\hline & 5.Sinıf ve üstü & 8 & 20.25 & 3.24 & & \\
\hline & TOPLAM & 195 & 16.33 & 4.12 & & \\
\hline \multirow{6}{*}{ Bilgi Eksikliği } & 1.Sinıf & 77 & 7.71 & 2.39 & \multirow{6}{*}{ - } & \multirow{6}{*}{0.302} \\
\hline & 2.Sinıf & 39 & 8.35 & 2.47 & & \\
\hline & 3.Sinıf & 29 & 8.44 & 2.38 & & \\
\hline & 4.Sinıf & 42 & 8.50 & 2.02 & & \\
\hline & 5.Sinıf ve üstü & 8 & 8.75 & 2.54 & & \\
\hline & TOPLAM & 195 & 8.16 & 2.34 & & \\
\hline \multirow{6}{*}{ Ulaşım Sorunu } & 1.Sinıf & 77 & 10.80 & 2.66 & \multirow{6}{*}{-} & \multirow{6}{*}{0.459} \\
\hline & 2.Sinif & 39 & 10.43 & 2.75 & & \\
\hline & 3.Sinif & 29 & 10.27 & 2.11 & & \\
\hline & 4.Sinıf & 42 & 10.47 & 2.39 & & \\
\hline & 5.Sınıf ve üstü & 8 & 12.00 & 2.32 & & \\
\hline & TOPLAM & 195 & 10.63 & 2.53 & & \\
\hline \multirow{6}{*}{ Tesis Yetersizliği } & 1.Sinıf & 77 & 11.94 & 2.10 & \multirow{6}{*}{-} & \multirow{6}{*}{0.203} \\
\hline & 2.Sinif & 39 & 12.28 & 2.37 & & \\
\hline & 3.Sinif & 29 & 11.82 & 2.13 & & \\
\hline & 4.Sinıf & 42 & 11.11 & 2.56 & & \\
\hline & 5.Sınıf ve üstü & 8 & 12.25 & 2.76 & & \\
\hline & TOPLAM & 195 & 11.83 & 2.30 & & \\
\hline \multirow{6}{*}{ Arkadaş Eksikliği } & 1.Sinıf & 77 & 7.97 & 2.01 & \multirow{6}{*}{-} & \multirow{6}{*}{0.525} \\
\hline & 2.Sinıf & 39 & 8.28 & 2.33 & & \\
\hline & 3.Sinif & 29 & 8.68 & 2.37 & & \\
\hline & 4.Sinıf & 42 & 8.11 & 2.12 & & \\
\hline & 5.Sınıf ve üstü & 8 & 8.87 & 2.16 & & \\
\hline & TOPLAM & 195 & 8.21 & 2.16 & & \\
\hline
\end{tabular}

$* \mathrm{p}<0.05$

Tablo 4'te, sınıf değişkenine göre karşılaştırma yapıldığında zaman ve ilgi eksikliği ile birey psikolojisi alt boyutlarında istatistiksel olarak anlamlı bir farklılık bulunmuştur ( $\mathrm{p}<0.05)$. Bilgi 
eksikliği, ulaşım sorunu, tesis yetersizliği ve arkadaş eksikliği alt boyutlarında istatistiksel olarak anlamlı bir farklılık bulunmamıştır $(\mathrm{p}>0.05)$.

\section{TARTIŞMA VE SONUÇ}

$\mathrm{Bu}$ bölümde bulgulardan elde edilen Üsküdar Üniversitesi'nde okuyan öğrencilerin rekreasyonel etkinliklere katılımına engel olan faktörlere ilişkin görüşlerine ait sonuçlar, araştırmanın sorularına cevap aranarak boş zaman engelleri çerçevesinde tartışılmış ve diğer literatürler ile karşılaştırılarak yorum yapılmıştır.

Elde edilen bulgulara göre, Üsküdar Üniversitesi öğrencilerinin rekreatif etkinliklere katılımını etkileyen faktörlerde büyük bir farklılığın olmadığı görülmektedir. "Cinsiyet" değişkenine göre karşılaştırıldığında alt boyutlarda istatistiksel olarak anlamlı bir farklılık bulunmamıştır ( $\mathrm{p}>0.05$ ). "Sınıf" değişkenine göre karşılaştırıldığında ise alt boyutlarda "zaman ve ilgi eksikliğgi" ile "birey psikolojisi”" alt boyutlarında istatistiksel olarak anlamlı bir farklılık bulunmuştur $(p<0.05)$. Üsküdar Üniversitesi öğrencileri sınıflar arasında zaman ve ilgi eksikliği ile birey psikolojisi alt boyutlarından kaynaklı rekreatif faaliyetlere katılmalarına engel olduğunu görülmektedir. Bundan kaynaklı olduğu düşünülerek öğrencilerin 151'i $(\% 77,4)$ boş zamanlarını kampüs dışında geçirdikleri görülmektedir. Bunun nedeni kampüs alanı içinde rekreasyon alanlarının yeterli olmadığına bağlanabilir. Ekinci, Kalkavan, Üstün ve Gündüz’ün (2014) çalışmasında üniversite öğrencilerinin \% 92,6'sının boş zamanlarını kampüs dışında geçirdiklerini belirttiler. Bu sonuç yapılan çalışmanın sonuçlarıyla benzerlik göstermektedir. Katılımcıların 109'u $(\% 55,9)$ sosyal etkinliklere, 29'u $(\% 14,9)$ kültürel-sanatsal etkinliklere, 24'ü $(\% 12,3)$ fiziksel aktivitelere, 17'si $(\% 8,7)$ ev içi aktivitelere, 9'u $(\% 4,6)$ açık alan etkinliklere, 7 'si $(\% 3,6)$ diğer etkinlik türlerine katılarak boş zamanlarını değerlendirdiklerini belirlenmiştir. Ekinci ve ark., (2014) üniversite öğrencileri üzerine yaptıkları çalışmalarında, \% 36' sının $(\mathrm{n}=122)$ boş zamanlarını ev içi aktivitelere katılarak, \%19,2' sinin sportif aktivitelere katılarak, \%26.8 ise kültürel/sanatsal etkinliklere katılarak değerlendirdiklerini belirtmiştir. Bu farklılığın nedeni, araştırmanın yapıldığı İstanbul ilindeki sosyal etkinliklerin Kütahya iline göre daha çeşitli olmasından dolayı kaynaklandığına bağlanabilir. 
Ekinci ve ark., (2014) çalışmasında katılımcıların boş zaman engellerinin cinsiyetlerine göre "bilgi eksikliğì", “arkadaş eksikliğì" ve "zaman” alt boyutlarında, yaşlarına göre "zaman" alt boyutunda, aylık ortalama gelir seviyelerine göre ise "birey psikolojisi" ve "tesisler/ hizmet" alt boyutlarında anlamlı farklılıklar gösterdiğini belirtmişlerdir. Demirel ve Harmandar'ın (2009) yaptığı çalışmada, katılımcıların boş zaman aktivitelerine katılımında en büyük engel olarak sosyal ortam ve bilgi eksikliğini gördükleri, bunu ise tesis/hizmet/ulaşım ve birey psikolojisi faktörlerinin takip ettiğini belirtmiştir. Çakır, Şahin, Serdar ve Parlakkılıç'ın (2016) yaptığı çalışmada, cinsiyetin serbest zaman engel düzeyleri açısından önemli ve anlamlı farklılık yaratan bir değişken olduğu, fakat aylık gelirin etken bir faktör olmadığını tespit etmişlerdir. Temir ve Gürbüz’ün (2012) yaptıkları çalışmada katılımcıların rekreasyonel aktivitelere katılımlarındaki zaman faktörünün ilk sırada yer aldığı buna karşın ilgi eksikliği faktörünün en alt sırada yer aldığı sonucuna varılmıştır. Çoruh'un (2013) yapmış olduğu çalışmada, ankette yer alan altı faktörün üçünde belirtilen bağımsız değişkenlere göre farklılaşmaların gözlemlendiği ancak, bu farklılaşmaların daha çok "zaman ve ilgi eksikliği" alt boyutunda yoğunlaştığı belirtilmiştir. Kahraman, Çolak, Bayazıt ve Yılmaz’ın (2017) yapmış olduğu çalışmada, spor lisesi ile anadolu lisesi öğrencileri karşılaştırıldığında ulaşım sorunu ile zaman ve ilgi eksikliği alt boyutlarında anlamlı farklılık tespit etmişlerdir. Şahin ve Kocabulut'un (2014) yapmış olduğu çalışmada, Alexandris ve Carrol tarafindan geliştirilen, toplam 7 alt boyut ve 27 maddeden oluşan "Boş Zaman Engelleri” ölçeğinden faydalanılmış; anket çalışması neticesinde elde edilen verilerle yapılan AFA Analizi'nde ise söz konusu ölçeğe ait iki ifadenin 7 alt boyuta ek olarak 8. boyut altında toplandığı görülmüştür. Elde edilen boyutun ise "yorgunluk hissi” olarak adlandırılmasını uygun bulmuşlardır. Paksoy, Çalık, Yaşartürk ve Çimen'in (2016) yapmış olduğu çalışmada, 1720 yaş aralığındaki öğrencilerin rekreasyon faaliyetleri tercih şekli ile 21 yaş ve üstü öğrencilerin rekreasyon tercihleri arasında anlamlı farklılık bulunmuştur. Öğrencilerin rekreasyon etkinliklerine katılımını; öğrencilerin yaş ve gelir düzeyi, kampüs fiziki ortamı, rekreasyon tercihlerinin niteliği, rekreasyona katılım şekli, rekreasyona yüklenen anlamın etkilediği sonucuna varılmıştır. Yaşartürk, Akyüz ve Karataş’ın (2017) yapmış olduğu çalışmada, serbest zamanlarında rekreatif etkinliklere katılan üniversite öğrencilerinin çeşitli faktörlere bağlı olarak "sıkılma" düzeyleri azaldıkça, yaşam doyum düzeylerinin arttı̆̆ı, ayrıca rekreatif etkinlikler içerisinde yer alan üniversite öğrencilerinin serbest zamanda algıladı̆̆ı “doyum” düzeyi arttıkça da, eş zamanlı olarak yaşam doyumu da artış göstermekte ve bu tür faaliyetler içerisinde daha 
verimli zaman geçirildiği belirtilmektedir. Ayhan, Eskiler ve Soyer'in (2017) yapmış olduğu çalışmada, aktif sporcuların genel olarak boş zaman değerlendirme etkinliklerine katılımlarında güçlük çektiği ve boş zamanlarını çoğunlukla dinlenerek, fiziksel ve sosyal aktivitelere katılarak geçirdiği belirtilmiştir. Ayrıca, aynı çalışmada boş zaman engellerinin arkadaş eksikliği ve zaman alt boyutlarında cinsiyete göre anlamlı farklılık bulunmuştur. Bu farklılıkların arkadaş eksikliğinde erkek sporculardan, zamanda ise kadın sporculardan kaynaklandığı belirtilmiştir. Soyer ve ark., (2017) yapmış olduğu çalışmada, boş zaman engellerinin "zaman” alt boyutunda cinsiyetler arasında anlamlı bir farklılık bulunduğu ifade edilmiştir.

Sonuç olarak, öğrenciler üniversitenin rekreasyon alanlarının yeterli olmadığını belirtmiştir. $\mathrm{Bu}$ bağlamda, boş zamanlarının büyük çoğunu kampüs dışında geçirdikleri görülmüştür. Boş zaman engelleri puanları cinsiyet değişkenine göre karşılaştırıldığında alt boyutlarda istatistiksel olarak anlamlı bir fark bulunmamıştır. Sınıf değişkenine göre karşılaştırıldığında ise alt boyutlarda "zaman ve ilgi eksikliği” ile "birey psikolojisi" alt boyutlarında istatistiksel olarak anlamlı bir fark bulunmuştur. Üniversiteler rekreasyon hizmetleri birimi oluşturarak, rekreasyon uzmanlarının öğrencilerin kampüs içinde boş zamanlarını daha fazla ve verimli geçirebilmeleri için sportif, kültürel, sosyal ve sanatsal etkinlikler planlamaları sağlanabilir.

\section{KAYNAKLAR}

Alexandris, K. \& Carroll, B. (1997). Demographic differences in the perception of constraints on recreational sport participation: Results from a study in Greece. Leisure Studies, 16(2), 107-125, [Available online at: https://www.tandfonline.com/doi/abs/10.1080/026143697375449], Erişim tarihi: 28 Mayıs 2017.

Axelsen, M. (2009). The power of leisure: I was an anorexic; I'm now a healthy triathlete. Leisure Sciences, 31(4), 330-346, [Available online at : https://www.tandfonline.com/doi/abs/10.1080/01490400902988283], Erişim tarihi: 20 Kasım 2018.

Ayhan, C., Eskiler, E. \& Soyer, F. (2017). Aktif sporcuların rekreatif etkinliklere katılımlarına engel oluşturabilecek faktörlerin yaşam tatmini ve yaşam kalitesi üzerine etkisi, Erpa Int. Congresses on Education, Hungary, 164-175.

Balcı, V. (2003). Ankara'daki üniversite öğrencilerinin boş zaman etkinliklerine katılımlarının araştırılması. Milli Ĕgitim Dergisi, 158, 161-173.

Çakır, V. O., Şahin, S., Serdar, E. \& Parlakkılıç, Ş. (2016). Kamu çalışanlarının serbest zaman engelleri ile yaşam tatmini düzeylerinin incelenmesi. Journal of Tourism Theory and Research, 2(2), 135-141.

Çoruh, Y., (2013). Üniversite ögrencilerinin rekreasyonel eğilimleri ve rekreasyonel etkinliklere katılımına engel olan faktörler: (Ăgrı İbrahim Çeçen Üniversitesi örneği). Yayınlanmamış doktora tezi, Gazi Üniversitesi Sağlık Bilimleri Enstitüsü, Ankara.

Demirel, M. \& Harmandar, D. (2009). Üniversite öğrencilerinin rekreasyonel etkinliklere katılımlarında engel oluşturabilecek faktörlerin belirlenmesi. Uluslararası Insan Bilimleri Dergisi, 6(1), 838-846, [Available online at: https://www. /profile/Demirel_Mehmet/publication/26618965_Determination_of_the_constraints_on researchgate.net_recreational _participation_of_university_students/links/569766f508aea2d7437519de.pdf], Erişim tarihi: 30 Mayıs 2017.

Ekinci, N. E., Kalkavan, A., Üstün, Ü. D. \& Gündüz, B. (2014). Üniversite öğrencilerinin sportif ve sportif olmayan rekreatif etkinliklere katılmalarına engel olabilecek unsurların incelenmesi. Sportif Bakış: Spor ve Ĕ̈itim Bilimleri Dergisi, 1(1), 1-13, [Available online at: http://dergipark.gov.tr/download/article-file/355491], Erişim tarihi: 30 Mayıs 2017. 
Bosna, O.Ş., Bayazıt, B., ve Yılmaz, O. (2018). Üniversite öğrencilerinin rekreasyonel etkinliklere katılımlarına engel olan faktörlerin incelenmesi (Üsküdar Üniversitesi Örneği). CBÜ Beden Eğitimi ve Spor Bilimleri Dergisi, 13(2), $200-211$.

Guo, J. \& Liu, X., 2016. College Students' Consciousness of Participation in Leisure Activities Behavior Related Research," International Journal of e-Education, e-Business, e-Management and e-Learning, 6(3), 186-192. [Available online at : http://www.ijeeee.org/vol6/404-JZ0127.pdf]

Gürbüz, B. \& Karaküçük, S. (2007). Boş zaman engelleri ölçeği-28: ölçek geliştirme, geçerlik ve güvenirlik çalışması. Gazi Beden Eğitimi ve Spor Bilimleri Dergisi, 12(1), 3-10. [Available online at: http://dergipark.gov.tr/download/articlefile/283474], Erişim tarihi: 29 Mayıs 2017.

Hendry, L. \& Marr, D. (1985). Leisure education and young people's leisure. Scottish Educational Review, 17(2), 116-27.

Iwasaki, Y. (2007). Leisure and quality of life in an international and multicultural context: What are major pathways linking leisure to quality of life?. Social Indicators Research, 82(2), 233-264, [Available online at : https://link.springer.com/article/10.1007/s11205-006-9032-z], Erişim tarihi: 20 Kasım 2018.

Kaba, İ. C. (2009). Türkiye'deki üniversitelerde kampüs rekreasyonun mevcut durumu ve kampüs rekreasyon modellemesi. Yayınlanmamış yüksek lisans tezi. Marmara Üniversitesi, İstanbul.

Kahraman, G., Çolak, E., Bayazıt, B. \& Yılmaz, O. (2017). Lise Öğrencilerinin Rekreasyonel Faaliyetlere Katılmalarını Etkileyen Faktörlerin İncelenmesi. Istanbul Üniversitesi Spor Bilimleri Dergisi, 7(1), 28-40, [Available online at: http://dergipark.gov.tr/download/article-file/337921], Erişim tarihi: 1 Haziran 2017.

Kemp, K. \& Pearson, S. (1997). Leisure and Tourism. Great Britain: Longman Press.

Özşaker, M. (2012). Gençlerin serbest zaman aktivitelerine katılamama nedenleri üzerine bir araştırma. Selçuk Üniversitesi, Beden Eğitimi ve Spor Bilimleri Dergisi, $14 \quad$ (1), 126, [Available online at: http://www.acarindex.com/dosyalar/makale/acarindex-1423931854.pdf], Erişim tarihi: 20 Kasım 2018.

Paksoy, M., Çalık, F., Yaşartürk, F. \& Çimen, K. (2016). Abdullah Gül Üniversitesi öğrencilerinin rekreasyon etkinliklerine katılımını etkileyen faktörler. International Journal of Science Culture and Sport (IntJSCS), 4(1), 39-50. [Available online at: http://www.iscsjournal.com/Makaleler/108516971_si1_5 paksoy.pdf], Erişim tarihi: 20 Kasım 2018.

Soyer, F., Yıldız, N. O., Harmandar Demirel, D., Serdar, E., Demirel, M., Äyhan, C. \& Demirhan, Ö. (2017). Üniversite öğrencilerinin rekreatif etkinliklere katılımlarına engel teşkil eden faktörler ile katılımcıların yaşam doyumları arasındaki ilişkinin incelenmesi. Journal of Human Sciences, 14(2), 2035-2046. doi:10.14687/jhs.v14i2.4647

Şahin, İ. \& Kocabulut, Ö. (2014). Sportif rekreasyon aktivitelerine düzenli katılımı engelleyen faktörlerin incelenmesi: Akdeniz üniversitesi turizm fakültesi öğrencileri üzerine bir araştırma. Journal of Recreation and Tourism Research, 1(2), 4667. [Available online at: https://www.researchgate.net/profile/Ilker_Sahin3/publication/312219091_Sportif_ Aktivitelerine_Duzenli_Katilimi_Engelleyen_Faktorlerin_Incelenmesi_Akdeniz_Universitesi_Turizm_Fakultesi_Ogre ncileri_Uzerine_Bir_Arastirma/links/587748ec08ae6eb871d149c6/Sportif-Rekreasyon-Aktivitelerine-DuzenliKatilimi-Engelleyen-Faktoerlerin-Incelenmesi-Akdeniz-Ueniversitesi-Turizm-Fakueltesi-Oegrencileri-Uezerine-BirArastirma.pdf], Erişim tarihi: 1 Haziran 2017.

Şener, A., Terzioğlu, R. G., \& Karabulut, E. (2007). Life satisfaction and leisure activities during men's retirement: a Turkish sample. Aging and Mental Health, 11(1), 30-36. [Available online at : https://www.tandfonline.com/doi/abs/10.1080/13607860600736349], Erişim tarihi: 20 Kasım 2018.

Temir, Ö. \& Gürbüz, B. (2012). Rekreasyonel aktivitelere katılımın önündeki engellerin incelenmesi, 1. Rekreasyon Araştırmaları Kongresi, Antalya.

Torkildsen, G. (2005). Recreation and leisure management. 5th Ed. London and New York: Routledge, Taylor and Francis Group.

Yaşartürk, F., Akyüz, H. \& Karataş, İ. (2017). Rekreatif etkinliklere katılan üniversite öğrencilerinin serbest zamanda sıkılma algısı ile yaşam doyum düzeyleri arasındaki ilişkinin incelenmesi. Uluslararası Kültürel ve Sosyal Araştırmalar Dergisi (UKSAD), 3(2), 239-252, [Available online at: http://dergipark.gov.tr/download/article-file/388848], Erişim tarihi: 20 Kasim 2018.

Yetim, A. (2005). Sosyoloji ve spor. İstanbul: Yaylacık Matbaası. 